\title{
Reading, Risk, and Reality: College Students and Reading for Pleasure
}

\section{Julie Gilbert and Barbara Fister}

\begin{abstract}
News reports and well-publicized government studies have led to a popular perception that reading is an endangered activity, particularly among youth. In this study we surveyed college students, librarians, and college writing instructors about students' attitudes toward reading for pleasure, examine barriers to voluntary reading among college students, and explore academic libraries' potential role in promoting reading. Our findings suggest that students have a far higher interest in reading than is typically believed and recommend steps academic librarians can take to encourage reading for lifelong learning.
\end{abstract}

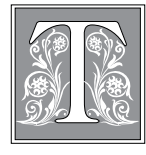

he news about reading is chronically catastrophic: Reading is at risk, ${ }^{1}$ in steep decline, ${ }^{2}$ imperiled particularly among young people, ${ }^{3}$ the "born digital" generation, so bewitched by Facebook, texting, and multichannel stimulation that their attention span has shrunk to the size of a tweet. ${ }^{4}$ Jeremiads about the decline of reading are common enough to constitute a genre. ${ }^{5}$ Should academic libraries, faced with tight budgets and ever-rising costs for digital subscriptions, do anything to encourage voluntary reading, given that all indications suggest our students are not likely to be interested?

This study asks several related questions: What are undergraduates' attitudes toward reading for pleasure? How do their experiences compare to academic librarians' perceptions of student reading habits and preferences? Do colleges and universities unknowingly erect barriers to reading for pleasure? Do academic librar- ies have any reason to encourage reading books and other material that does not directly support the curriculum and, if so, what methods would students favor?

To address these questions, we administered surveys about recreational reading to college students at one institution and to academic librarians nationally. For the purposes of the study, we define "recreational reading" as any reading voluntarily undertaken that has not been assigned for class. We include magazines, newspapers, and the Internet as sources of recreational reading, in addition to books. We also use the term "recreational reading" interchangeably with "leisure reading," "reading for fun," and "reading for pleasure." We supplemented our findings by conducting an exploratory small-scale survey of writing instructors, by probing conflicting claims about the purposes of reading made by teachers of literature and on Web sites of college reading in common programs, and by examining the

Julie Gilbert is Academic Librarian, Assistant Professor, and Barbara Fister is Academic Librarian, Professor, at the Folke Bernadotte Memorial Library at Gustavus Adolphus College; e-mail: Jgilber2@gustavus. edu,fister@gustavus.edu.C Julie Gilbert and Barbara Fister 
content of writing samples from students enrolled in an elective course on books and culture to see what motivates their feelings about reading.

We were surprised by what we learned. Students may not find time to do much voluntary reading; but, if what they tell us is true, they do take pleasure in reading and would welcome efforts from libraries to help them discover reading material.

\section{Differences between Voluntary Reading and Academic Reading Practices}

There is a body of compelling evidence that reading for pleasure is beneficial, ${ }^{6}$ not just for increasing literacy but because information encountered in leisure reading informs readers about the world they live in and about themselves. ${ }^{7}$ Reading for pleasure has been associated with creativity $^{8}$ and with improved academic achievement..$^{9}$ Some argue that reading literature achieves many of the goals of liberal education and can have a profound effect on individuals' lives. ${ }^{10}$

Reading assignments are commonly used in the college years to convey information in greater depth than can be accomplished in class or to provide exposure to important primary literature in a discipline. Students often need help in learning how to do "close" or in-depth analytical reading. In the field of literary studies, learning to read imaginative literature critically often involves overcoming common and ingrained reading practices. Critical reading requires avoiding being absorbed in a story - one of the great pleasures of the reading experience ${ }^{11}$ - if that emotional involvement inhibits analysis. As one English professor put it, students need to learn that reading, which may seem effortless, is actually quite difficult. Students' enjoyment in reading literature, he reported, "proved a serious obstacle to the students' ability to think critically about the works and their own thinking. It created a kind of 'transparency effect' in the reading experience, preventing students from getting very far toward reading in deliberate and self-conscious ways." Unskilled readers tend to focus on what is happening to the characters and must actively resist the lure of being spellbound by the story in order to read well. "Only trained readers have the skills to negotiate, back and forth, the relation between the textualities of fiction and its sublime imaginary constructions." 12 A goal of his teaching is to turn naïve readers into sophisticated ones, learning to go beyond discussing the story to focus on how the story works.

In a practical book of advice for literature teachers, Elaine Showalter points out $^{13}$ that teachers who are themselves novelists often teach reading fiction as a way of discovering the narrative shape and meaning of one's own life; but, more commonly, English teachers, trained in literary criticism, teach students to avoid identification with characters. To read critically means to understand how a story is constructed and to relate one text to another through thematic or chronological connections. Though close reading can provide its own pleasures of discovery, Showalter acknowledges that many readers feel it is no substitute for feeling transported.

Rita Felski has argued that enchantment as a quality of the reading experience is underrated by her fellow literary scholars because it is associated with women's supposed tendency to succumb to escapist fare and because it is believed to be a cheap sleight-of-hand trick performed by profit-driven mass media concerns. She writes,

While much modern thought regulates such hyper-saturations of mood and feeling to the realm of the child-like or the primitive, the accelerating interest in affective states promises enchantment is richer and more multi-faceted than literary theory has allowed; it does not have to be tied to a haze of romantic nostalgia or an incipient fascism. Indeed, enchantment may 
turn out to be an exceptionally fruitful idiom for rethinking the tenets of literary theory. ${ }^{14}$

It may be that endorsing the power of enchantment as a legitimate purpose for literature might sanction students' selfdirected reading. According to a study of students' beliefs about reading, Lydia Burak ${ }^{15}$ found that students who believe reading engages their imaginations and is not a waste of time report the highest motivation to read outside of class. Of the 201 students she surveyed, 63 percent reported having read a book for pleasure in the past semester. Over 90 percent agreed with the statements that reading increases knowledge, improves vocabulary, and engages the imagination; 70 percent felt it relieves stress; only a tiny minority of 5 percent agreed with the statement that it was a waste of time.

Others who teach college literature feel that popular literacy practices could be studied in the classroom ${ }^{16}$ or that the kinds of reading practiced by book clubs might provide insights that could be useful to teachers of literature. ${ }^{17}$ Still others have focused their research entirely on reading that happens outside academia, such as Janice Radway's study of romance readers ${ }^{18}$ and Elizabeth Long's research into women's book groups. ${ }^{19}$

\section{Reading and the College Experience}

The handful of studies that have been conducted on college students' recreational reading practices suggest that students themselves see voluntary reading and assigned reading very differently. A 1991 survey of over 300 seniors at a small public liberal arts institution found that 88 percent of them engaged in reading for pleasure, favoring literature and current events as subject matter. ${ }^{20} \mathrm{~A}$ more recent study $^{21}$ of 539 students who completed time-diary surveys found that "using the Internet" was more popular with students than recreational reading, but that Internet use did not appear to displace reading as an activity. Watching television was less popular than reading for pleasure, but students were more likely to watch some television every day than to read for pleasure. Reading assigned texts was the least popular of the four activities, but it consumed much of their time. In a small-scale study by Hari and Joliffe at a large public university, students kept detailed reading logs that demonstrated they read a lot, both online and in print, the subjects recording an average of 25 minutes a day reading print sources not assigned for class and about twice that much time reading online sources such as e-mail, Facebook, and other Web sites. "We found students who were actively involved in their own programs of reading aimed at values clarification, personal enrichment, and career preparation," the authors reported. "In short, we discovered students who were extremely engaged with their reading, but not with the reading that their class required." 22

One site for examining the contested nature of reading is the "summer reading" or "reading in common" programs that have sprouted up on college campuses in recent years. They typically involve asking incoming first-year students to read a book in common for discussion during orientation. Programming, such as an author visit, film viewing, or other events may complement the reading activity. Adopted from the popular community reads movement started by Nancy Pearl in Seattle in 1998, reading in common programs straddle the book club orientation to reading as an opportunity to discuss a book informally with others in a social setting and the eat-your-vegetables imperative of an assigned reading. A 2007 survey of college and university staff who administer such programs ${ }^{23}$ found that faculty involvement was listed as a strength when it was present, and as a challenge when it was not. An examination of Web pages ${ }^{24}$ of over 100 such programs suggests their goals, rather than stressing the development of close reading skills and an understanding of literary traditions emphasized in many 
English courses, are more focused on building community, making the transition to college, exploring personal values, and examining social issues. Though the words "intellectual" and "academic" often appear in these statements of purpose, the supporting materials tend to be marketing information from publishers' Web sites and discussion questions that, like many book discussion guides, emphasize using the book discussion as a vehicle for developing personal insights and social engagement.

Academic and public libraries have typically defined their roles in regard to reading promotion very differently. In public libraries, readers' advisory has seen a renaissance, though provision of factual information remains a significant mission of public libraries. Academic libraries, as a site of teaching, learning, and discovery, tend to focus on helping students and faculty find resources for their work. While public libraries strive to help their patrons discover reading material of choice, academic libraries are more focused on locating materials that will support a task. Could academic libraries help provide a bridge between the kinds of reading that Joliffe and Hari found engages students and the "institutional" reading that undergirds the college curriculum?

Several academic libraries have pursued recreational reading promotions. Julie Elliott has twice surveyed academic librarians about reading promotions in their libraries and the barriers librarians perceive to recreational reading on college campuses. In 2007, Elliott ${ }^{25}$ found that libraries engage in a variety of reading promotion activities, such as one-book programs, leisure reading collections, and book lists. Librarians reported several barriers toward promotion, such as impact on staff time and collection development budgets, lack of training in readers' advisory services, and a fear that promoting recreational reading makes libraries look less academic. In 2009, Elliott reported ${ }^{26}$ that librarians continue to find lack of funding and the impact on staff time to be significant barriers, as well as the lack of interest in some staff to participate, perceived low levels of student interest in leisure reading, and acting within a culture that does not value reading.

Tom Kirk recently reviewed the status of "browsing collections" at academic libraries and has suggestions for using technology to help students develop the habit of reading beyond required texts, arguing that libraries should cultivate curiosity; otherwise, the library may "drift into an abdication of responsibility for promoting reading among its students." ${ }^{27}$ Pauline Dewan also makes a case for creating popular reading collections in academic libraries." 28 Ann Salter and Judith Brook surveyed undergraduates at two institutions ${ }^{29}$ and discovered that a majority of respondents read for pleasure and are perhaps not as aliterate as recent studies indicate. Salter and Brook further encourage libraries to promote recreational reading. Renee Bosman, John Glover, and Monique Price ${ }^{30}$ support a blog, a book swap and a READ program in their library in part as a way to support the library as what Ray Oldenburg ${ }^{31}$ has called a "third place" - a social community setting that is not the workplace and not home-where students can feel comfortable both relaxing and learning. Heidi Gauder, Joan Giglierano, and Christine H. Schramm ${ }^{32}$ developed a Porch Reads program at the University of Dayton that facilitates book discussions among sophomore students and faculty; students have responded positively to the program. Bette Rathe and Lisa Blankenship $^{33}$ established a recreational reading collection at their library that is separate from the rest of the collection. A brief survey of students who use the collection report they appreciate a smaller, easier-tonavigate collection. Rochelle Smith and Nancy J. Young ${ }^{34}$ have provided practical ways of highlighting leisure reading already in a library's collection, such as book lists, displays, tools such as NoveList, as well as using instruction sessions 
as an opportunity to inform students they can also use the Reference Desk to find recreational reading. Finally, Mardi Mahaffy ${ }^{35}$ outlined ways academic libraries can sponsor reading outreach programs, describing two programs facilitated by the New Mexico State University Library.

\section{The Study}

To probe the notion that college students are part of a demographic in which reading is at risk, we surveyed our students about their attitudes and experiences with recreational reading; we also surveyed academic librarians. The site of the student survey, Gustavus Adolphus College, is a small, private liberal arts college located in southern Minnesota, educating approximately 2,500 undergraduates. Our students are primarily of "traditional" ages, 18-22; and, though the college is selective, data from the Wabash National Study of Liberal Arts Education ${ }^{36}$ examining the incoming class of 2006 found that our students on entering college were no more likely to engage in unassigned reading than students at all institutions in the study, regardless of size, institution type, or selectivity.

We conducted the student survey during spring 2009. The survey instrument was developed in-house by two librarians working with an undergraduate research scholarship recipient; survey questions targeted student attitudes toward reading, current practices, and perceived barriers (Appendix A). The scholarship recipient administered the survey to the campus community by targeting faculty who taught a variety of class levels in a range of disciplines and asking permission to administer and collect the survey during class, reaching 28.7 percent of the student body. Students in every class were informed that their participation in the survey was anonymous and completely voluntary. We received 717 completed surveys from students who are a representative sample of class year, gender, and majors at Gustavus.

Our survey of academic librarians, which was developed by the authors, mirrors the student survey in several ways (Appendix B). While surveying students directly at other institutions was beyond the scope of this study, the librarian survey addresses perceptions of undergraduate reading habits on various campuses and what measures, if any, academic librarians were taking to promote leisure reading. We surveyed librarians subscribed to the ILI-L e-mail list $^{37}$ maintained by the Instruction Section of the Association of College and Research Libraries as well as to reference and instruction librarians at the 80 liberal arts colleges that are members of the Oberlin Group ${ }^{38}$ via group e-mail lists. We received 342 responses from librarians at a variety of institutions. Survey results from both student and librarian surveys were entered into the SPSS statistical package to generate descriptive statistics and to analyze relationships among key variables.

\section{Reading at Gustavus}

Undergraduate students on our campus report overwhelmingly that they like to read for pleasure; almost all respondents $(93.0 \%)$ report that they enjoy leisure reading. Although women are slightly more likely than men to report that they enjoy leisure reading $(95.6 \%$ of women compared to $88.7 \%$ of men), the high percentage of men who enjoy reading is encouraging, especially in light of studies indicating that men are less likely to enjoy reading than women..$^{39}$ We saw little difference in reading patterns by class year; this is perhaps not surprising, as the majority of undergraduates at our institution are grouped closely in age. We do see slight variation by majors, however. ${ }^{40}$ Humanities majors are almost unanimous in their enjoyment of leisure reading (99.0\%), while preprofessional (nursing, education, health, physical education, and exercise science) majors and social science majors report the lowest levels of reading enjoyment, though approximately 90 percent of them report enjoying reading. 
Still, we found significant differences in reading habits among students in different majors.

Students read broadly across a number of genres (see table 1). Students report that general fiction is by far the most popular, followed by mysteries, classics, and general nonfiction. It should be noted that our genre categories were open to interpretation by respondents; a novel by Jane Austen might be considered a classic by one student and counted as general fiction by another. Also, there were several categories, such as graphic novels, that were not specified on the survey but appeared frequently as write-in choices. The table does show us, however, that our students have a wide range of reading interests and that they are mainly interested in reading fiction of one sort or another.

Men are twice as likely as women to read science fiction, but women are slightly more likely than men to read fantasy. Perhaps not surprisingly, women are much more likely to read romance than men. Women are also more interested in reading general fiction, as almost nine in ten women read fiction compared to over half of men. ${ }^{41}$ Women and men report reading nonfiction at about the same rates, however. There are slight variations by class year, as first-year students were slightly less likely to read biographies and other nonfiction than their peers $(15.3 \%$ of first-year students read biographies as compared to $26.0 \%$ of other class years combined). A little less than one in five first-year students $(19.8 \%)$ reads nonfiction, while results from the other classes combined were closer to 1 in 3 (35.3\%).

There are notable differences among majors. For example, humanities majors are overwhelmingly more likely to read classics than any other group of students. They are also more likely to read fantasy novels than their classmates. Natural science majors are over two and a half times more likely to read science fiction than fine arts majors and over three times more likely to read science fiction than preprofessional majors. They are also far less likely to read biographies and autobiographies. Preprofessional majors are more likely to read romance novels. Finally, fine arts students are even slightly more likely than humanities majors to read general fiction. The emerging differences exhibited by students according to major has implications both on how we build our collection of recreational reading and also how we market it to various groups of students.

We asked respondents to provide

\begin{tabular}{|l|c|c|c|c|c|c|c|c|}
\hline \multicolumn{7}{|c|}{ TABLE 1 } \\
\hline & What Do They Like to Read? (By Genre) & (Percentages) \\
\hline & $\begin{array}{l}\text { Science } \\
\text { Fiction }\end{array}$ & Fantasy & Romance & Mystery & Classics & $\begin{array}{c}\text { General } \\
\text { Fiction }\end{array}$ & $\begin{array}{c}\text { Bio/ } \\
\text { Autobio }\end{array}$ & $\begin{array}{c}\text { General } \\
\text { Nonfiction }\end{array}$ \\
\hline $\begin{array}{l}\text { All } \\
\text { Respondents }\end{array}$ & $\mathbf{2 4 . 5}$ & $\mathbf{2 9 . 5}$ & $\mathbf{2 8 . 1}$ & $\mathbf{3 8 . 9}$ & $\mathbf{3 3 . 7}$ & $\mathbf{7 6 . 9}$ & $\mathbf{2 3 . 4}$ & $\mathbf{3 1 . 4}$ \\
\hline Women & 16.0 & 31.0 & 42.4 & 44.6 & 37.3 & 87.8 & 23.7 & 31.0 \\
\hline Men & 37.8 & 26.7 & 4.1 & 29.7 & 27.4 & 58.3 & 22.6 & 32.0 \\
\hline Major & & & & & & & & \\
\hline Humanities & 28.0 & 42.0 & 28.0 & 43.0 & 65.0 & 86.0 & 27.0 & 38.0 \\
\hline $\begin{array}{l}\text { Social } \\
\text { Science }\end{array}$ & 20.3 & 26.6 & 28.5 & 40.1 & 28.0 & 71.0 & 27.1 & 30.4 \\
\hline $\begin{array}{l}\text { Natural } \\
\text { Science }\end{array}$ & 38.2 & 29.5 & 20.2 & 34.7 & 30.6 & 75.7 & 16.8 & 33.5 \\
\hline $\begin{array}{l}\text { Pre- } \\
\text { professional }\end{array}$ & 10.4 & 25.5 & 37.7 & 43.4 & 22.6 & 79.2 & 25.5 & 31.1 \\
\hline Fine Arts & 15.9 & 30.2 & 31.7 & 38.1 & 39.7 & 90.5 & 25.4 & 34.9 \\
\hline
\end{tabular}




\begin{tabular}{|l|c|c|c|}
\hline \multicolumn{4}{|c|}{ TABLE 2 } \\
Newspapers, Magazines, and the Internet (Percentages) \\
\hline All Respondents & Newspapers & Magazines & Internet \\
\hline Women & $\mathbf{5 1 . 2}$ & $\mathbf{6 4 . 1}$ & $\mathbf{4 3 . 9}$ \\
\hline Men & 44.3 & 67.0 & 37.5 \\
\hline Major & 62.8 & 59.4 & 54.9 \\
\hline Humanities & & & 50.0 \\
\hline Social Science & 51.0 & 50.0 & 48.3 \\
\hline Natural Science & 56.5 & 66.2 & 45.7 \\
\hline Preprofessional & 48.6 & 63.0 & 38.7 \\
\hline Fine Arts & 48.1 & 69.8 & 39.7 \\
\hline
\end{tabular}

specific examples of the works they like to read in both fiction and nonfiction. Simply having this list will be useful for our collection development purposes, as it points out gaps in our collection. We saw a range of fiction titles that fall into various categories:

- Young adult fantasy titles, including the Harry Potter and Twilight series, as well as Philip Pullman's His Dark Materials series and Jonathan Stroud's Bartimaeus Trilogy

- Bestselling authors such as Dan Brown, Jodi Picoult, and Nicholas Sparks, all of whom appeared frequently on students' lists

- Chick lit such as the Gossip Girl and Shopaholic series

- Horror and adventure authors, including Stephen King and Clive Cussler

- Literary fiction, such as works written by Joyce Carol Oates, Margaret Atwood, and Khaled Hosseini

- Or, as one student summed up, "Pretty much anything"

Students identified nonfiction preferences more by topic than by specific title, singling out interests in history, religion (especially Christianity ${ }^{42}$ ), true crime, and science.

Over half of all students report that they like to read newspapers, and over two-thirds of students indicate they enjoy reading magazines (see table 2). Recognizing that students spend a lot of time read- ing and composing on social networks, we specifically asked students to exclude those sites when thinking about their reading patterns on the Internet; with that constraint, less than half report they like reading for pleasure on the Internet. The findings do indicate, however, that students do consider the Internet a source for recreational reading.

Table 2 indicates differences by gender, including the fact that, while women are more likely to read magazines, men are more likely than women to read newspapers and pursue reading on the Internet. While there are not significant differences among majors regarding their likelihood of reading newspapers, we do note some differences regarding whether or not they read magazines or read for pleasure on the Internet. Students also read a variety of newspapers, magazine, and Internet sources, including major newspapers; a wide range of magazines including sports, lifestyle, gossip, and news magazines; and primarily news and sports sites on the Internet. In addition to confirming the hypothesis that students include magazine, newspaper, and the Internet in their understanding of leisure reading, the data provide us with multiple magazine and newspaper titles that students prefer.

We also asked students approximately how many hours a week they spend reading for pleasure during the school 
year (see table 3). Though students report enjoying reading, most of them spend very little time reading anything that isn't assigned. While differences between class year and gender were not significant, we again found some differences by major. At least one-fourth of students in each major division read less than two hours (but more than one hour) per week. Humanities majors read for pleasure at a higher rate than other students; almost one in five humanities majors reads three or more hours per week. On the other end of the scale, almost half of preprofessional majors read for pleasure less than one hour a week, followed closely by almost half of fine arts students. This is compared to one-third of natural science and social science majors and one in five Humanities majors.

\section{Librarians' Perceptions of Students' Leisure Reading Practices}

In our survey of academic librarians, we learned that a large percentage of librarians believe students do not particularly enjoy reading for pleasure and that there was some ambivalence about the role academic libraries should play in reading promotion. We asked librarians about how often in their experience students came to the library looking for recreational reading materials. Almost two-thirds $(61.0 \%)$ report that students "occasionally" look for recreational reading materials in their libraries. Close to one-tenth $(9.2 \%)$ said "very frequently," but almost one-third (29.1\%) said they rarely see students looking for recreational reading materials in their library. Almost no one said students never look for recreational reading materials. Although we cannot directly compare the librarian survey data to the data about Gustavus students, we can note that both surveys suggest students at academic institutions appear to have some degree of interest in recreational reading.

We also asked librarians about their perceptions of what students prefer to read (see figure 1). (Results are presented alongside responses from Gustavus students for comparison purposes, even though librarians at other institutions could serve student populations that are significantly different from Gustavus students.) The findings have a few things in common with what our students report: general fiction is very popular, as is genre fiction. We also asked survey respondents to comment on specific titles or genres that they see their students reading. Librarians report that their students seek Christian fiction, young adult titles, graphic novels, ethnic literature, and current bestsellers. In short, librarians at other institutions report that their students exhibit interest in a wide variety of materials.

\section{Barriers to Recreational Reading: The Students' Perspective}

We asked Gustavus students about the barriers they face for recreational reading during the academic year (see table

\begin{tabular}{|l|c|c|c|c|c|}
\hline \multicolumn{7}{|c|}{ TABLE 3 } \\
Number of Hours Spent Leisure Reading per Week (Percentages) \\
\hline & Zero & Less than 1 & Less than 2 & Less than 3 & $\mathbf{3 +}$ \\
\hline All Respondents & $\mathbf{1 0 . 0}$ & $\mathbf{3 4 . 5}$ & $\mathbf{2 9 . 6}$ & $\mathbf{1 4 . 0}$ & $\mathbf{1 1 . 7}$ \\
\hline Major & & & & & \\
\hline Humanities & 13.0 & 20.0 & 24.0 & 23.0 & 20.0 \\
\hline Social Science & 8.7 & 33.8 & 29.5 & 15.5 & 12.1 \\
\hline Natural Science & 11.6 & 32.9 & 34.7 & 10.4 & 10.4 \\
\hline Preprofessional & 10.4 & 48.1 & 25.5 & 9.4 & 6.6 \\
\hline Fine Arts & 7.9 & 44.4 & 25.4 & 7.9 & 14.3 \\
\hline
\end{tabular}




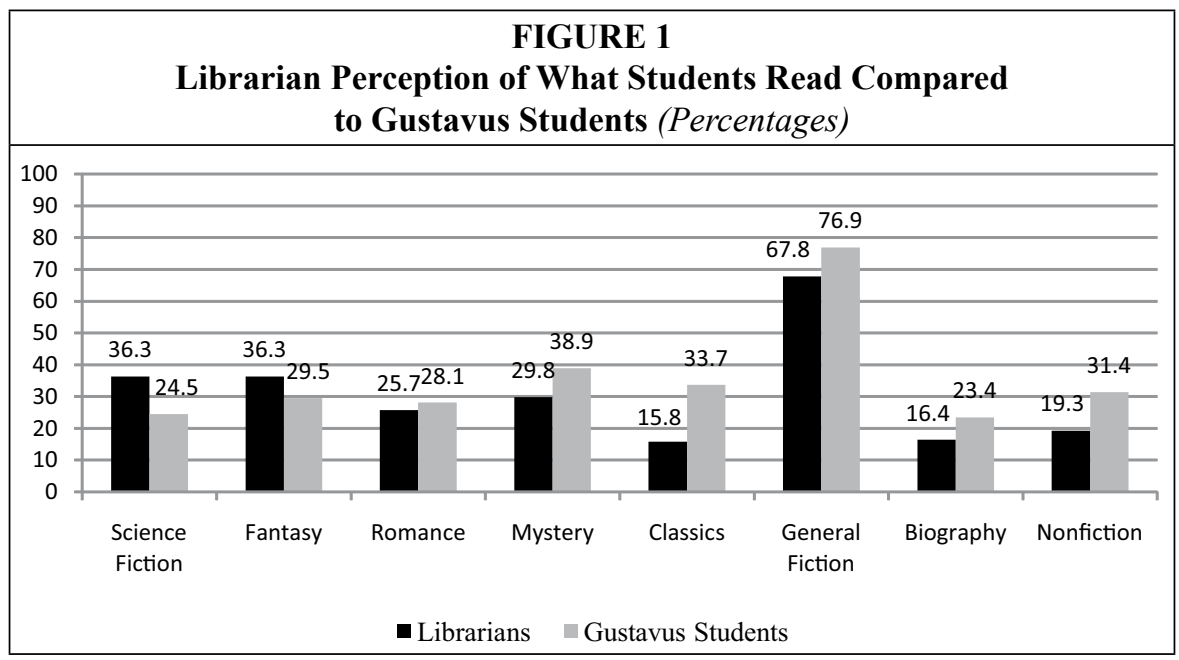

4). The categories we constructed contain overlap in terms of time; a student indicating he or she has too much reading for class, would rather socialize, and would rather spend his or her time in other ways all relate to the broader question of lack of time. Although the question was perhaps biased in its emphasis on time constraints, the students were also given space to comment on the barriers they face to leisure reading. Respondents could choose as many options as apply.

Even with the overlapping categories, it is clear that the barriers to reading for pleasure do not relate to enjoyment or access. Lack of time to read for pleasure, whether because of homework, a desire to socialize, or a decision to spend time in other ways, is the primary constraint. This pattern does not vary significantly by class year or gender, although women are slightly more likely than men to indicate they already have enough to do for class. Once again we find that the bigger differences arise by major. Humanities and fine arts majors are less likely than their counterparts to say they already have enough to do for class. Humanities majors are also less likely than other students to say they would rather spend their time socializing or spend it in other ways.

Responses in the open-ended question

\begin{tabular}{|l|c|c|c|c|c|}
\hline \multicolumn{7}{|c|}{ TABLE 4 } \\
\hline & $\begin{array}{c}\text { Don't } \\
\text { Enjoy It }\end{array}$ & $\begin{array}{c}\text { Already Have } \\
\text { Enough Reading } \\
\text { for Class }\end{array}$ & $\begin{array}{c}\text { Would Rather } \\
\text { Socialize }\end{array}$ & $\begin{array}{c}\text { Would Rather } \\
\text { Spend Time in } \\
\text { Other Ways }\end{array}$ & $\begin{array}{c}\text { Lack } \\
\text { Access }\end{array}$ \\
\hline $\begin{array}{l}\text { All } \\
\text { Respondents }\end{array}$ & $\mathbf{3 . 3}$ & $\mathbf{7 7 . 1}$ & $\mathbf{3 5 . 7}$ & $\mathbf{3 1 . 2}$ & $\mathbf{3 . 3}$ \\
\hline Major by Discipline & 0.0 & 68.0 & 19.0 & 17.0 & 4.0 \\
\hline Humanities & 4.8 & 80.7 & 36.2 & 32.4 & 2.9 \\
\hline Social Science & 2.3 & 74.6 & 38.2 & 37.0 & 4.6 \\
\hline Natural Science & 5.7 & 83.0 & 39.6 & 31.1 & 1.9 \\
\hline Preprofessional & 5.7 & 36.5 & 27.0 & 1.6 \\
\hline Fine Arts & 1.6 & 69.8 & & \\
\hline
\end{tabular}


are not surprising to anyone familiar with college campuses. Among other activities, students indicate that they prefer to work out, spend time with friends, watch TV and movies, participate in extracurricular activities, and sleep. One local college bar was listed as a priority several times. By far, the most common response to our open-ended question was that students were busy with other activities and classwork. Comments include:

- "Not enough physical hours in the day to do much else but go to class, do homework and occasionally sleep."

- "NO TIME. Class reading is ridiculous, so leisure reading gets put off."

- "After homework it is hard to read for fun."

- "I enjoy it but it just doesn't make the top of my priority list."

- "Don't have much free time."

- "My mind needs a break!"

Judging by these comments, lack of time emerges as the biggest barrier our students face in reading for pleasure.

\section{Barriers Reported by Librarians at Other Institutions}

We provided similar options for librarians at other colleges and universities in terms of perceived barriers to student recreational reading (see figure 2). A majority of respondents indicate that they feel students believe they have too much reading to do for class already and that they would rather spend their free time in other ways, such as socializing. Survey respondents also highlight the additional issues they perceive related to interest and access.

Nearly 40 percent of librarian survey respondents report that they perceive that students aren't interested in reading for pleasure, while one in five believe that students lack access to recreational reading materials. Comments gleaned from the open-ended question reveal several interrelated themes: a concern about the demands placed on student time, the gap between what the students want to read and what the library contains in its collections, and issues of access:

- "Students at the school where I work are almost uniformly working fulltime and also going to school."

- "Our recreational reading collection is very small because we are limited in shelf space."

- "It's hard to tell if they're not interested. Our budget is so limited that we can't buy too much rec. fiction, and I get the sense that if students can't find a book they want at our library they don't go to the public library to find it, even though there's a branch nearby and we suggest it to them."

- "Lack of a visible, clearly-labeled shelving area for recreational fiction."

- "Language barriers - we have a

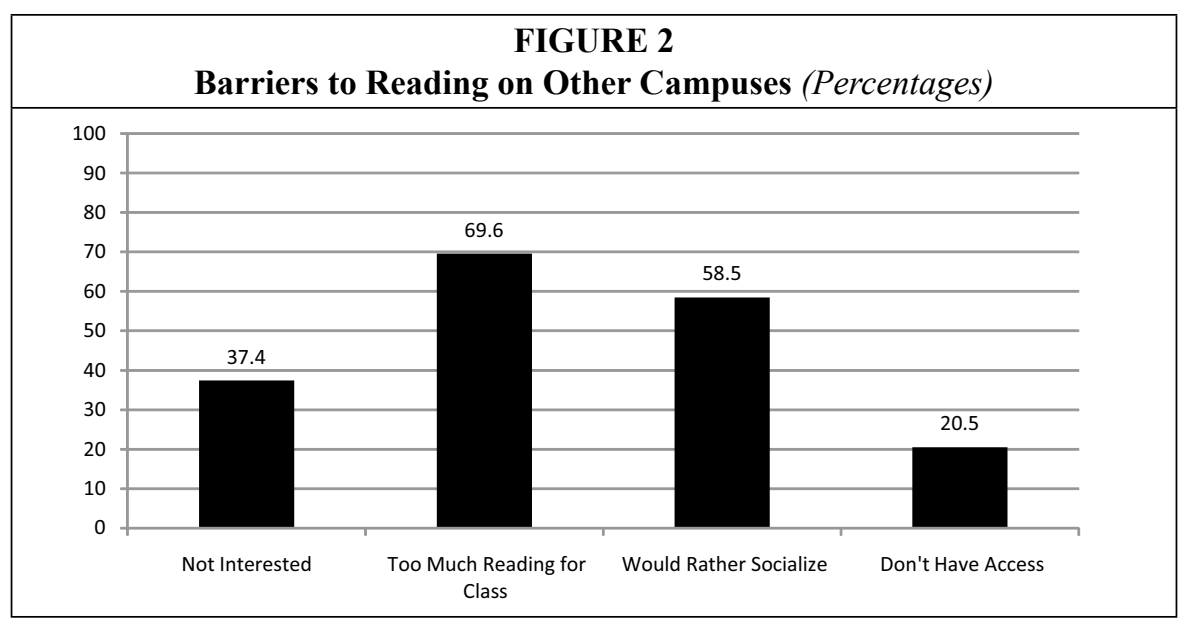


high percentage of students who are ESL and/or speak another language at home."

- "Our popular fiction is somewhat limited, and interfiled in the stacks with the rest of the literature collection. Students who want to find something fun and escapist to read often have trouble locating it."

Librarians identified a final barrier through comments provided to a final open-ended question: Should academic libraries play a role in promoting recreational reading? Some respondents indicated that purchasing recreational reading violated both formal and informal collection development policies:

- "We have many students asking for popular material. Our collection policy doesn't provide for it and the reference staff is seeking to change that policy."

- "I constantly have to defend my sci-fi and fantasy purchases to folk who think students should be reading more intellectual material."

Other respondents cite inherent barriers along the lines of a lack of time, energy, and funds, which are precious commodities within libraries:

- "I believe this is an area that in general academic libraries have not focused heavily upon, but I think more of us would like to rethink this. There are also some external constraints-limited funding and justifying to the administration (and maybe a few classroom faculty) the need to spend funds on recreational reading in an academic library."

- "Sadly, it is at the bottom of my to-do list. I think that is because it is not directly related to any curriculum at my institution."

Finally, for other respondents, it comes down to a question of core mission. A few respondents commented that promoting leisure reading is not part of the mission of academic libraries, exemplified by this comment: "Is active promotion of recreational reading really part of our mission, and should those materials be part of our permanent collection? Part of me says no ... that our focus should be more academic." However, many respondents believe that reading promotion is an important function for academic libraries, as typified by this comment: "One of our six fundamental goals of the library is facilitating the appreciation and celebration of books. We view this not as a separate program but as an integrated, integral part of our students' education."

\section{Addressing the Barriers}

Gustavus students have many ideas of how the library could help address barriers to reading (see figure 3 ), while also noting through their responses to openended questions that they do not expect the library to address all barriers. We devised the list of options from staff sug-

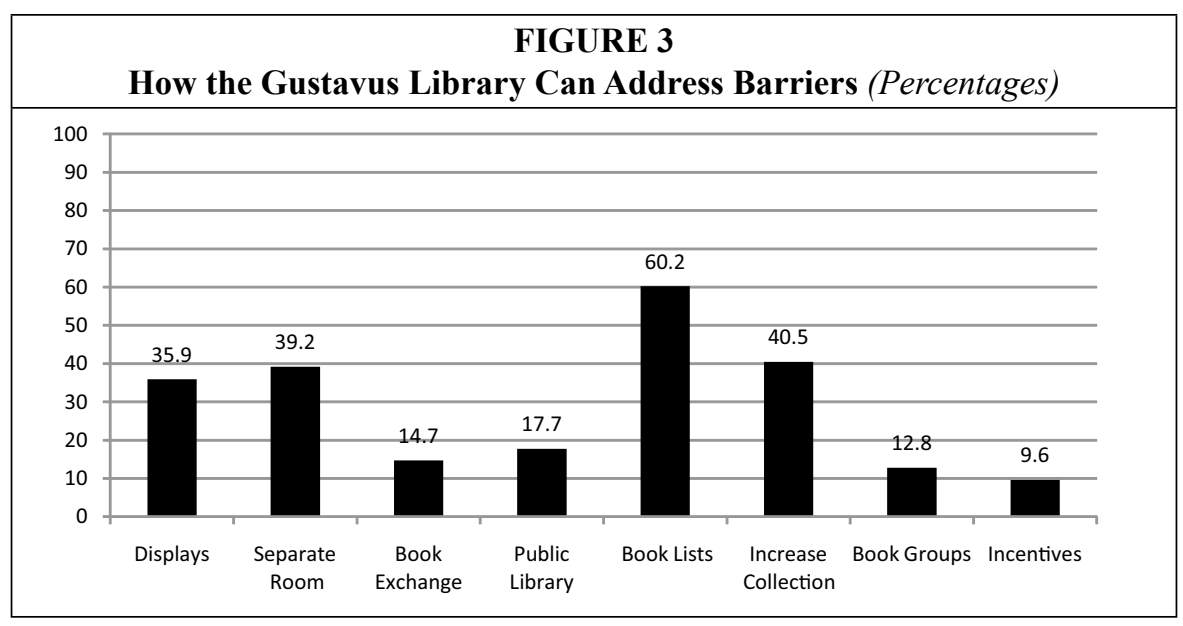


gestions and activities we already do in part. We also included programs we have encountered at other libraries. Essentially, we wanted to gather student-focused data that we could put to practical use in our library.

Students at Gustavus feel that recommended book lists would be the most helpful of our suggestions. In informal conversations with students about the results, several said they were not surprised book lists ranked so highly, hypothesizing that book lists would help students find books they could read on breaks and vacations from school. Students would also like more options for recreational reading, with 40.5 percent indicating they would like us to increase the collection. To a lesser extent, students also expressed interest in more displays and having a separate room for leisure reading. This probably connects to the difficulty students have in browsing for leisure reading the way they can in a bookstore or public library. Quite a few students are unaware that the library even has fiction, since they are used to it being shelved alphabetically by author in a separate section. Although less than one in ten indicated an interest in incentives, students suggested several types of incentives the library could offer, mainly involving prizes for reading a certain number of books or offering refreshments such as pizza, ice cream - or beer.

Many open-ended responses duplicated options in the survey question, such as increasing the collection and creating more displays. Students asked for extended loan periods over summers and other holidays, as well as promoting the fact that leisure reading can be requested through Interlibrary Loan. Students had suggestions for specific types of books to add to the collection, such as more graphic novels and magna. They would also like to know what their classmates are reading, and several respondents mentioned having students write book reviews for the campus newspaper. Several students responded that they wanted more com- fortable furniture in the library to create an environment more suitable for curling up with a good book. Additionally, several advocated for fiction, nonfiction, and poetry sections in an environment more like a bookstore. Finally, several comments indicate that the library can only solve part of the problem; students recognize that sometimes they simply do not have the time to read for pleasure during the school year:

- “There's not a whole lot the library can do. It all has to do with the amount of time students have."

- "Tell profs to lighten up on the workload. Ha ha."

- "Lobby for less homework."

- "Help people realize they have more time for it than they think."

- "People aren't going to leisure read when all their time is spent reading/writing for class."

- "I love to read and it kills me not to be able to do it more often (aka at all) during the school year."

We also asked librarians about the kinds of reading promotion activities they use (see figure 4).

Almost two-thirds of libraries (62.3\%) use displays to promote books; over half (53.2\%) also have a designated separate area for their recreational reading collection. Close to one-third (29.8\%) use signs as well. Figure 4 also indicates that almost all of libraries surveyed provide some services related to leisure reading promotion; only 7.5 percent of respondents do no recreational reading promotion at their libraries. Through an open-ended question, librarian respondents also provided many examples of the other types of promotion they use, such as providing leased books, reading lists, reading contests, activities related to National Library Week, or sponsored readings from faculty and students during Black History and Women's History Months. Almost one in five collaborate with a local public library in some manner, predominantly through reciprocal borrowing and shared programming. 


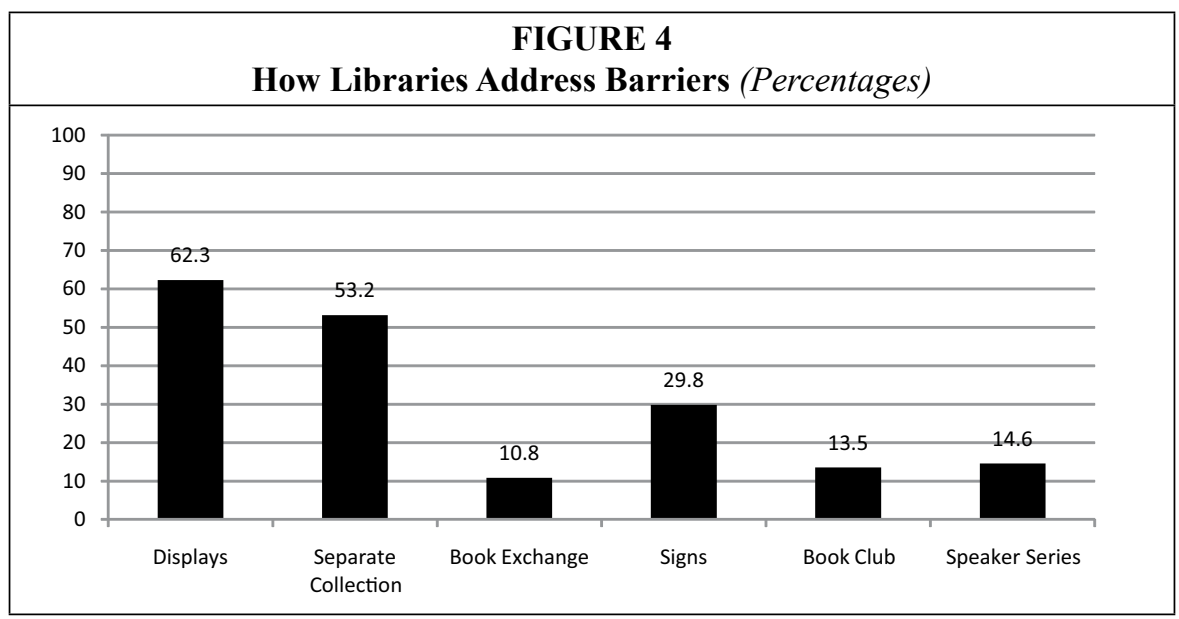

\section{Voices of Writing Instructors}

Though we did not have an opportunity to conduct a large-scale study of faculty perceptions, a brief online survey was distributed in the spring of 2010 to writing instructors who are members of WPA-L, a listserv loosely affiliated with the Council of Writing Program Administrators that has been an active electronic gathering place for college composition teachers since 1993. The survey questions can be found in Appendix C.

The 48 respondents were divided about whether reading is in steep decline among young people, though a majority disagreed or disagreed strongly with that statement. What counted as reading was an issue for respondents. "If by reading, you mean reading 'books' I think this is true," one stated, adding, "if using a broader definition of reading as engaging some kind of visual text, then I disagree." One respondent stated, "it's not in decline; it's just shifting to different kinds of texts," while others pointed to the popularity of Harry Potter and the Twilight series. One wrote, "I would say that I have noticed that all of my students read recreationally, and some are even passionate about their recreational reading - but that passion tends not to carry over into their academic reading."

They were also divided about the notion that students' facility with reading fiction interfered with their ability to approach texts critically, though a majority disagreed with that claim. "Reflection after pleasure is wonderfully critical," one wrote. "It might require training to do that - but that is what we are doing, right? Opening up not only sites of inquiry, but reflective practices as well." Another said, "We know from a variety of research that students tend to try to treat all texts as narratives -'story' is a way they think about reading as a whole."

There was strong agreement with the claim that reading fiction, even when the writing is weak by literary standards, can be beneficial. "No problem with reading all kinds of junk," one commented. "I read thousands of terrible comic books growing up and I don't think it did irreparable harm."

Slightly over 40 percent of respondents agreed with the statement that reading practices fostered in popular culture, such as Oprah's Book Club or book-related social networking sites such as GoodReads, differ significantly from reading practices taught in college classrooms. One said, "[T]his is basic community-of-practice theory. People who read in different activity systems, for different purposes, and use texts as tools in different ways, will of course read in significantly different ways from each other. It would be freakish if 
they didn't." Another wrote, "[F]aculty are quite skilled at making even the most wonderful books deadly boring. Another key point is the flexibility of the reader choosing what to read and when to read." One respondent pointed out that social reading practices tend to emphasize identification with characters and with personal experience. "I think these communities emphasize personal connections to literature more than other kinds of analysis - that 'relatability' that students are always talking about. And classroom studies move well beyond the relationship of books to individual personal experience." However, nearly as many respondents chose either "neutral" or "don't know" in response to this question as agreed with the statement and another 23 percent disagreed with it.

When it came to speculating about barriers to reading for pleasure, faculty in this limited survey were slightly more likely than academic librarians to believe that students simply do not enjoy reading, with 44 percent of respondents agreeing or agreeing strongly with this statement. Only a quarter disagreed with this notion. Wanting to spend free time on other things, or being too busy with jobs and family responsibilities, were perceived as significant barriers by nearly all respondents. In contrast, being busy with assigned reading was perceived as a barrier by only 60 percent of respondents.

Open-ended comments included the following: "I think that we need to create a space for encouraging students to read recreationally within the academic setting" and "[T]he kinds of assignments students are required to do in curricula designed for high stakes testing deserve significant blame for the decline in schooled reading and schooled reading pleasure." Things were not much different now than in the past, according to one respondent. "Many of my students still love to read. In addition, I have many non-traditional students who love reading and discussing literature, something they have never had the opportunity to do. I also have students who don't enjoy reading. This has been true for the thirty years I have been teaching." Another respondent was clearly frustrated by the claim made in NEA reports and elsewhere that reading is "at risk."

This is getting so clichéd, I hate to repeat it, but: the notion that students are less textual might've worked 10 or even 5 years ago but, by sheer weight of how students are actually spending their time, can't work anymore. Student out-ofschool production of text-which, we forget, by definition necessitates reading of text-is higher than it's ever been. Texting, chatting, social networking, and multimodal/ mashup writing are huge onlinetime takers ... Reading, for the people who worry about this, is supposed to be done for its own sake. Reading for communication or some other end doesn't, for these folks, seem to count. And students "these days" are actually using texts, not just reading them ... so the hell-ina-handbasket crowd is in a froth. I think we need a reimagining, from them, of what counts as "reading."

\section{Students Write about Reading}

Finally, we wanted to include in this study some reflections on reading by students in their own words. In January 2009, 27 Gustavus students who were enrolled in a month-long interim experience course on Books and Culture ${ }^{43}$ wrote reflectively in response to a number of prompts about their reading experiences. At the end of the course, they used their writings to compile a zine, comic, chapbook, or digital project. Though clearly the students who choose to take a course on this subject are not representative of students generally, their reflections suggest that the pleasure students take in reading is closely associated with memories of comfort and closeness and that they feel what they choose to read voluntarily is an 
expression of who they are. The following passages, drawn from various student projects, provide insight into these affective dimensions of reading.

It was an ordinary place in our house growing up, but it became magical every night when my mom would sink into the soft cushions with a book in her hands. My younger sister and I would sit on either side of her resting our heads against her arms, peering at the illustrations that transformed our living room. My mom's voice would decode the squiggles on the page into words, into a story. My first memory of books comes from this spot in our living room.

My earliest memory of the library was of story time at my hometown public library. The head librarian's name was Mrs. Pease. She would sit and read to us while we crowded around her in a certain spot in the library to hear a wonderful story told in her animated voice ... I felt very comforted by the readings she read to us because that is what my family members always did with me.

My mom and I would curl up on her bed, and she would read [Little House on the Prairie] as Laura's life played out in my head. When she was happy, having fun, I was smiling without even realizing it. When she was scared or in trouble, I was bouncing around the bed in a subconscious attempt to relieve the tension. A constant dialogue developed between my mom and I:

Mom: Are you scared? Do you want to stop?

\section{Me: No!!! Keep going!}

You know how you hear people talk about how a certain song, a certain food, perhaps a certain smell evokes a memory as strong as if you are reliving it at that very moment? Well, that happens to me, too. Except it's not songs or smells that draw my unsuspecting mind through time. It's books.

My bookshelf is not just a bookshelf. It's a time warp.

Though, when the course was taught, the Kindle had recently been released and was getting a lot of press attention, these students were largely skeptical about electronic books. In writing about the future of books, they often referred to tactile pleasures as well as the relaxation they felt traditional forms of reading offered.

I like to research on the Internet, but reading too much off a screen hurts my eyes. I enjoy the feel, smell, and texture of a book in my hands. It is captivating and something you can only experience with a book. I think that the technology should just enhance the book and the printed copy will not die.

Computers are highly distracting. I find reading should be a way to distract all of us from the "distracting" part of our lives instead of bringing more.

Though these students cannot be considered "typical," their responses provide support for the claim that reading is a relaxing and pleasurable activity and that the books they have chosen to read over the years have become an essential component of their sense of self. Given that such a vast majority of their peers claim to enjoy reading, these written responses round out our understanding of why students find voluntary reading pleasurable.

\section{Discussion}

We were quite surprised by the results of our student survey. Though students 
report they do not have much time to engage in reading for pleasure during the school year, they have strongly positive feelings about reading, and that positive feeling extends to a variety of reading choices, including books, newspapers, and magazines. While students may not seek out pleasure reading during the school year, it would seem worthwhile to help students sustain their interest when they do have more free time-during school breaks and over the summer. Students expressed an interest in having help identifying books they might enjoy so that when they do have time, they are prepared with options. This suggests that academic libraries may not need to address students' interest in recreational reading through collection development, but rather through some form of quickaccess reader's advisory geared to college students' interests. We noted differences among various student populations in terms of preferred reading materials, suggesting that reader's advisory work should be targeted to specific groups of students; for example, since natural sciences students prefer science fiction to a greater degree than their colleagues, the library might consider advertising science fiction collections more to these students.

Librarians (and a limited sample of faculty who teach writing and literature) who were surveyed underestimate students' desire to read material of their own choosing. This suggests that it may be worthwhile to explore with faculty leaders where cultivating reading as a component of lifelong learning falls in the institution's mission and overall learning outcomes. There are also implications for information literacy programs, which tend to focus on finding and evaluating material that will be used for college assignments, an extrinsic motivator that ceases with graduation. These skills are not likely to be transferrable for finding fulfilling reading material based on intrinsic motivation and not tied to information needs per se. Are there ways that academic libraries and the curriculum in general could better bridge the gulf between schooled reading and the kind of reading that Victor Nell calls "ludic" intense, absorbed, and transporting? ${ }^{44}$

At Gustavus, we have taken some immediate steps as a result of these findings. In a response to students' preference for booklists and a request for suggestions from their professors, we queried classroom faculty about recommended reading. Our first round yielded over a hundred recommendations from about a dozen faculty members. A staff member created bookmarks, which are displayed in the library and include the name of the faculty member who made the recommendation. We plan on soliciting recommendations once a semester and will use faculty recommendations to create book displays. We are also developing a Web site that will contain all of the recommendations, along with other suggestions for recreational reading and directions for finding recreational reading within our collections.

After noting that students tend to read more when they are on breaks or during summer vacation, we tweaked our circulation policies to allow for extended loan periods, including a three-month loan extension over summer for returning students. We have advertised the extension and several students have taken advantage of the longer loan periods.

Last summer we also created a separate fiction section as part of a pilot project that might ultimately lead us to rearrange our entire Language and Literature $(\mathrm{P})$ section. Our goal was to create a fiction section reminiscent of a public library or bookstore. After soliciting recommendations from library staff, we culled approximately 200 fiction books representing a variety of genres from our permanent collection. We arranged the books alphabetically by author on a set of shelves in a newly created reading room. The books were tagged with green spine stickers, and we changed the catalog records to communicate their new location within the building. We promoted the new col- 
lection through signs, blog postings, and table tents in the cafeteria. After tracking circulation patterns over the academic year, we were initially dismayed to see that the books did not fly off the shelves as fast as we hoped. Enough books circulated, though, to encourage us to run a second year of the pilot program. In the coming year we will promote the display to a greater degree and collect feedback from students about the usefulness of such an arrangement.

Recognizing that students enjoy reading magazines, as evidenced by the study, we have also turned our periodicals collection into a circulating collection. Students can check out periodicals for a period of seven days; the policy boosts student use of the collection, including use of literary and popular magazines. We rearranged some of the shelving in our current periodicals section to create cozy reading and study nooks, hoping to increase serendipitous discovery of reading material.

We also have begun offering a partial credit book discussion course taught by librarians. Students read a book in common, selected and announced before registration, and also read books of their own choosing, meeting weekly for group discussion. We envision this new course as an "intellectual activity" course, similar to the partial credit physical activity courses offered at the college. ${ }^{45}$

All of these efforts will require assessment to determine the extent of the impact on college students' recreational reading practices. We envision our assessment efforts will involve direct querying of students, whether through surveys, interviews, written reflections, or focus groups, to determine both the effective- ness of specific activities as well as the overall effort the library is undertaking to promote recreational reading on campus.

\section{Conclusion}

Our surveys of students, academic librarians, and a small number of college writing instructors suggest that college students enjoy reading for pleasure to a far greater degree than previous reports would indicate. High-profile studies that have concluded reading is in decline discount reading that is required for work or school. Our survey suggests that this limited definition of reading (that eliminates all but voluntary reading and, in the case of the 2004 NEA report, Reading at Risk, focused solely on voluntary reading of fiction, plays, and poetry) may have been profoundly misleading. Clearly, our students feel the reading they do for classes competes with voluntary reading, but their enjoyment in reading and their expressed desire to read material of their own choosing indicates that reading is, in fact, thriving.

Academic libraries provide academic resources for students while they are enrolled, but they also hope to promote habits of lifelong learning. A substantial body of reading research suggests that the primary factor in reading proficiency is pleasure in the experience. ${ }^{46}$ If we want our students to continue to read after college, we should look beyond helping them succeed as students, but also consider ways to help them develop their personal reading tastes, learn effective ways to identify satisfying reading material, and instill an expectation that they can turn to libraries after college for their continued education and development. 


\section{Appendix A: Student Survey}

1. Year in School

$\square$ First Year $\square$ Sophomore $\square$ Junior $\square$ Senior

2. Sex

$\square$ Male $\square$ Female

3. Major: (open ended)

4. Do you enjoy reading in general?

$\square$ Yes $\square$ No

5. Do you enjoy leisure reading?

$\square$ Yes $\square$ No

6. What do you like to read for leisure? (Check all that apply)

$\square$ Science Fiction

$\square$ Fantasy

$\square$ Romance

Mystery

Classics

$\square$ Fiction (please specify)

Biography/Autobiography

$\square$ Nonfiction (please specify)

Newspapers (please specify)

$\square$ Magazines (please specify)

Internet (please specify)

7. How much time do you spend leisure reading per week during the school year?

$\square 0$ hours

Less than one hour

More than one hour but less than two hours

More than two hours but less than three hours

More than three hours

8. If you do not leisure read or do not leisure read as much as you would like during the school year, why not? Check all that apply.

$\square$ I don't enjoy it.

I already have enough reading to do for class

$\square$ I would rather socialize

$\square$ I would rather spend my free time in other ways (please specify)

I don't have access to leisure reading materials that I am interested in.

$\square$ Other (please specify)

9. How might the library better encourage leisure reading at Gustavus? (Check all that apply)

More displays/browsing area

$\square$ Create a separate room devoted to leisure reading collections

Create a book exchange program

$\square$ Collaborate more with the public library 
$\square$ Create popular book lists

Expand popular book collections

$\square$ Offer more book groups

$\square$ Offer incentives (please specify)

$\square$ Other (please specify)

10. Is there anything else you would like to share with us about your leisure reading habits or how the library can better encourage leisure reading at Gustavus?

\section{Appendix B: Librarian Survey}

1. Are you a librarian at an academic institution?

$\square$ Yes $\square$ No

2. In your experience, do students in general come to the library looking for recreational reading?

$\square$ Very frequently $\square$ Occasionally $\square$ Rarely $\square$ Never $\square$ Not sure

3. In your experience, what kind of recreational reading materials are students generally looking for? (Check all that apply)

$\square$ Science fiction

$\square$ Fantasy

Romance

$\square$ Mystery

Classics

$\square$ General fiction

$\square$ Autobiography/biography

$\square$ Other nonfiction

$\square$ Other (please specify)

4. In your experience, what are some of the barriers students encounter with recreational reading? (Check all that apply)

$\square$ They feel they have too much reading to do for classes already.

They aren't interested in reading.

They would rather spend their time in other ways (socializing, etc.)

They don't have access to recreational reading materials.

$\square$ Other (please specify)

5. In which of the following recreational reading promotion activities does your library participate? (Check all that apply)

$\square$ Book clubs (coordinating or hosting)

$\square$ Book displays

Book exchange program

- Separate browsing/popular book collection

$\square$ Signs (either promotional or directional)

$\square$ Speaker series

$\square$ None of the above

$\square$ Other (please specify)

6. Please select the type that best describes your institution:

$\square$ 2-year college $\square$ 4-year college $\square$ Master's degree granting $\square \mathrm{Ph} . \mathrm{D}$.degreegranting 
7. Please share any additional thoughts or comments you have about recreational reading promotion in academic libraries.

\section{Appendix C: Faculty Survey}

This brief survey is intended to complement surveys of academic librarians and of undergraduates enrolled at a Midwestern liberal arts college on the subject of undergraduate students' leisure reading preferences and habits. (Leisure reading includes any form of reading material-books, magazine articles, web-based texts, etc. - that students read voluntarily out of class.) Results will be incorporated into an article in progress that will be submitted to a journal of academic library research. The survey is anonymous and you may exit at any time. Any questions or concerns may be addressed to Barbara Fister, one of the co-investigators.

The survey asks for responses to general statements. Though the general statement are too reductionist to answer easily, please indicate the response closest to your feeling (though it's understood that you probably can't simply agree or disagree with statements that have no context and are overbroad; an optional comment box is available after each question if you would like to elaborate).

[Options were agree strongly, agree, neutral, disagree, disagree strongly, and don't know. Each question also offered space for comments.]

1. Reading is in steep decline, particularly among people under age 22.

2. One teacher ${ }^{47}$ reported his students found it easier to read fiction than other kinds of literary texts, but that their pleasure and facility "provided a serious obstacle to the students' ability to think critically about the works and their own thinking." In general, do you agree or disagree?

3. Reading popular fiction for fun can be valuable for students, even if the writing is weak by literary standards (such as novels by Dan Brown or Nicholas Sparks).

4. Reading practices fostered in popular culture (like Oprah's Book Club, online book-focused communities such as GoodReads) are significantly different from reading practices taught and developed in college classrooms.

5 . The majority of young people today are easily distracted multitaskers who have more difficulty with sustained reading than did students of previous generations.

6. All things being equal, students prefer to read digital texts rather than printed ones.

7. Major factors that inhibit undergraduates from reading for pleasure include the following:

- They don't enjoy reading

- They are busy reading material assigned for classes

- They prefer to spend their free time in other ways

- They often have jobs and/or family responsibilities, which means they have little time for leisure activities

- They don't have easy access to the kind of reading material they prefer

- English language learners are a significant portion of my students, and they often have difficulty reading for any reason

8. Is there anything you'd like to add about college students and recreational reading? 


\section{Notes}

1. National Endowment for the Arts, Reading at Risk: A Survey of Literary Reading in America (Washington, D.C.: National Endowment for the Arts, 2004). Available online at http://www.nea. gov/pub/readingatrisk.pdf [Accessed 20 July, 2011].

2. Ursula K. LeGuin, "Staying Awake: Notes on the Alleged Decline of Reading," Harpers (Feb. 28, 2008), 33-38.

3. National Endowment for the Arts, To Read or Not to Read: A Question of National Consequence (Washington, D.C.: National Endowment for the Arts, 2007), available online at http://arts.endow. gov/research/ToRead.pdf [Accessed 20 July, 2011]; Mark Bauerlein, The Dumbest Generation: How the Digital Age Stupefies Young Americans and Jeopardizes Our Future (Or, Don't Trust Anyone Under 30) (New York: Penguin, 2008).

4. Nicholas Carr, "Is Google Making Us Stupid? What the Internet is Doing to Our Brains," Atlantic Monthly (July/Aug. 2008), 56-83. Available online at www.theatlantic.com/magazine/ archive/2008/07/is-google-making-us-stupid/6868/. [Accessed 20 July, 2011].

5. An early example of this type is Sven Birkerts, The Gutenburg Elegies: The Fate of Reading in an Electronic Age (Boston: Faber and Faber, 1994).

6. Catherine Sheldrick Ross, Lynne (E.F.) McKechnie, and Paulette M. Rothbauer, Reading Matters: What the Research Reveals about Reading, Libraries, and Community (Westport, Conn.: Libraries Unlimited, 2006).

7. Catherine Sheldrick Ross, "Finding without Seeking: What Readers Say about the Role of Pleasure Reading as a Source of Information," Australasian Public Libraries and Information Services 13, no. 2 (June 2000): 72-80; Jessica Moyer, "Learning from Leisure Reading: A Study of Public Library Patrons," Reference and Users Services Quarterly 46, no. 4 (2007): 66-79; Richard Gerrig, Experiencing Narrative Worlds: On the Psychology of Reading for Pleasure (Boulder, Colo.: Westview, 1998); Jessica E. Moyer, Research-Based Readers' Advisory (Chicago: ALA, 2008).

8. Kathryn E. Kelly and Lee B. Kneipp, "Reading for Pleasure and Creativity among College Students," College Student Journal 43, no. 4 (Dec. 2009): 1137-44.

9. Jude D. Gallik, "Do They Read for Pleasure? Recreational Reading Habits of College Students," Journal of Adolescent E Adult Literacy 42, no. 6 (Mar. 1999): 480-88.

10. Mark Edmundson, Why Read? (New York: Bloomsbury, 2004); Daniel R. Schwarz, In Defense of Reading: Teaching Literature in the Twenty-First Century (Malden, Mass.: Blackwell: 2008).

11. Victor Nell, Lost in a Book: The Psychology of Reading for Pleasure (New Haven, Conn.: Yale University Press, 1988).

12. Jerome McGann et al., "'Reading Fiction/Teaching Fiction': A Pedagogical Experiment," Pedagogy: Critical Approaches to Teaching Literature, Language, Composition, and Culture 1, no. 1 (2001): 144-45.

13. Elaine Showalter, Teaching Literature (Malden, Mass.: Blackwell, 2003).

14. Rita Felski, Uses of Literature (Malden, Mass.: Blackwell, 2008), 76.

15. Lydia Burak, "Examining and Predicting College Students' Reading Intentions and Behaviors: An Application of the Theory of Reasoned Action," Reading Horizons 45, no. 2 (2004): 139-53.

16. R. Mark Hall, "The 'Oprafication' of Literacy: Reading 'Oprah's Book Club,'” College English 65, no. 6 (July 2003): 646-67; Deborah Brandt, "Sponsors of Literacy," College Composition and Communication 49, no. 2 (May 1998): 165-85.

17. Jane Missner Barstow, "Reading in Groups: Women's Clubs and College Literature Classes," Publishing Research Quarterly 18, no. 4 (Winter 2003): 3-17.

18. Janice A. Radway, Reading the Romance: Women, Patriarchy, and Popular Literature (Chapel Hill: University of North Carolina Press, 1984).

19. Elizabeth Long, Book Clubs: Women and the Uses of Reading in Everyday Life (Chicago: University of Chicago Press, 2003).

20. Charlene Blackwood et al., "Pleasure Reading by College Students: Fact or Fiction?" (paper presented at the Annual Meeting of the Mid-South Educational Research Association, Lexington, Ky., Nov. 13-15, 1991, ERIC ED344191).

21. Kouider Mokhtari, Carla A. Reichard, and Anne Gardner, "The Impact of Internet and Television Use on the Reading Habits and Practices of College Students," Journal of Adolescent $\mathcal{E}$ Adult Literacy 52, no. 7 (Apr. 2009): 609-19.

22. Allison Hari and David A. Joliffe, "Texts of Our Institutional Lives: Studying the 'Reading Transition' from High School to College: What Are Our Students Reading and Why?" College English 70, no. 6 (July 2008): 600.

23. Andrew Twiton, Common Reading Programs in Higher Education (Jan. 2007). Available online at http://gustavus.edu/academics/library/Pubs/Lindell2007.html. [Accessed 20 July, 2011].

24. Barbara Fister, One Book, One College: Common Reading Programs. Available online at http:// 
homepages.gac.edu/ fister/onebook.html. [Accessed 20 July, 2011].

25. Julie Elliott, "Academic Libraries and Extracurricular Reading Promotion," Reference \& User Services Quarterly 46, no. 3 (Spring 2007): 34-43.

26. Julie Elliott, "Barriers to Extracurricular Reading Promotion in Academic Libraries," Reference E User Services Quarterly 48, no. 4 (Summer 2009): 340-46.

27. Tom Kirk, "What Has Happened to Browsing Collections in Academic Libraries?" Library Issues 30.5 (July 2011): 4.

28. Pauline Dewan, "Why Your Academic Library Needs a Popular Reading Collection Now More than Ever," College \& Undergraduate Libraries 17, no. 1 (Jan.-Mar. 2010): 44-64.

29. Anne Salter and Judith Brook, "Are We Becoming an Aliterate Society? The Demand for Recreational Reading among Undergraduates at Two Universities," College \& Undergraduate Libraries 14, no. 3 (Sept. 2007): 27-43.

30. Renee Bosman, John Glover, and Monique Prince. "Growing Adult Readers: Promoting Leisure Reading in Academic Libraries," Urban Library Journal 15, no. 1 (Spring 2008). Available online at http://lacuny.org/ulj/index.php/past-issues/36-151/62-growing-adult-readers-promotingleisure-reading-in-academic-libraries. [Accessed 10 July 2011].

31. Ray Oldenburg, The Great Good Place: Cafes, Coffee Shops, Community Centers, Beauty Parlors, General Stores, Bars, Hangouts, and How They Get You Through the Day (New York: Paragon House, 1989).

32. Heidi Gauder, Joan Giglierano, and Christine H. Schramm, "Porch Reads: Encouraging Recreational Reading Among College Students," College \& Undergraduate Libraries 14, no. 2 (June 2007): $1-24$.

33. Bette Rathe and Lisa Blankenship, "Recreational Reading Collections in Academic Libraries," Collection Management 30, no. 2 (Apr. 2005): 73-85.

34. Rochelle Smith and Nancy J. Young, "Giving Pleasure Its Due: Collection Promotion and Readers' Advisory in Academic Libraries," Journal of Academic Librarianship 34, no. 6 (Nov. 2008): $520-26$.

35. Mardi Mahaffy, "In Support of Reading: Reading Outreach Programs at Academic Libraries," Public Services Quarterly 5, no. 3 (July 2009): 163-73.

36. For more information about the study, see the Center of Inquiry in the Liberal Arts, Wabash National Study of Liberal Arts Education. Available online at www.liberalarts.wabash.edu/studyoverview/. [Accessed 20 July, 2011].

37. Information about this list can be found online at www.ala.org/ala/mgrps/divs/acrl/about/ sections/is/ilil.cfm. [Accessed 20 July, 2011]. It currently has over 4,000 members.

38. "Oberlin Group Members," Oberlin Group. Available online at www.oberlingroup.org/ members. [Accessed 20 July, 2011].

39. Michael W. Smith and Jeffrey D. Wilhelm, "Reading Don't Fix No Chevys": Literacy in the Lives of Young Men (Portsmouth, N.H.: Heinemann, 2002).

40. Majors at Gustavus are grouped into five divisions: education (including preprofessional majors such as nursing, education, and exercise science), fine arts, humanities, mathematics and natural sciences, and social sciences (including economics and management). The list of majors and the divisions they belong to can be found online at https://gustavus.edu/academics.php. [Accessed 20 July, 2011].

41. This finding is consistent with previous studies of reading and gender such as Steven J. Tepper's “Fiction Reading in America: Explaining the Gender Gap," Poetics 27, no. 4 (May 2000): $255-75$.

42. Though Gustavus is affiliated with the Lutheran church (ELCA), librarians at nonaffiliated institutions also reported that students expressed interest in Christian reading material.

43. The course syllabus and supporting materials can be found online at http://booksandculture.wordpress.com/. [Accessed 20 July, 2011]. Students agreed to have their written responses analyzed and quoted anonymously for research purposes.

44. Nell, Lost in a Book.

45. Course objectives and syllabus can be found at http://readingshop.wordpress.com/ [Accessed 25 July 2011]

46. Ross et al., Reading Matters, 4.

47. Jerome McGann et al, "'Reading Fiction/Teaching Fiction': A Pedagogical Experiment," Pedagogy: Critical Approaches to Teaching Literature, Language, Composition, and Culture 1.1 (2001): 143-165. 